\title{
Greenland Adventure: 1935 Diary of a very young man, age 20
}

\section{by M.J. Dunbar}

This is the diary, unedited and in its original form, of one member of a four-man student expedition to Greenland. All the members were approximately the same age, all Oxford undergraduates, and the purpose of the enterprise was the survey of an area in West Greenland south of Holsteinsborg. Two of us, Henry Hayward and Peter Mott, were engineering students and had some considerable knowledge of surveying. The other two, Michael Atter and myself, were officially "back-packers," or general support. Mike Atter was drowned in the Sarfartok River, a large, swift and muddy river draining the ice-cap. It is mainly in his memory that this diary is published; but it is also offered as a personal statement by a very young man, member of an expedition that made no claim to immortality in the annals of exploration.

Il s'agit du journal intime, inédit et dans sa version originale, de l'un des membres d'une expédition de quatre étudiants au Groenland. Tous avaient à peu près le même âge, tous étaient des étudiants de $1^{\text {er }}$ cycle d'Oxford et avaient pour mission d'arpenter une région située dans l'ouest du Groenland et au sud de Holsteinborg. Deux d'entre nous, Henry Hayward et Peter Mott, étaient étudiants en génie et avaient une connaissance approfondie de l'arpentage. Michael Atter et moi-même étions leurs "aides". Mike Atter s'est noyé dans la Sarfartok, rivière large, tumultueuse et boueuse drainant la calotte glaciaire. C'est essentiellement à sa mémoire que ce journal est publié; publication offerte comme le témoignage personnel d'un très jeune homme, membre d'une expédition qui n'a jamais prétendu à l'immortalité dans les annales de l'exploration.

\section{PREFACE}

During the late summer of 1990, Max Dunbar visited me in Greenland, his first visit to this land in almost fifty years. This was an exceptional pleasure to me and together we travelled in the region of Godthåb (Nuuk), flew through the Sarfartok' Valley near Søndre Strømfjord and went by boat and helicopter around icebergs in Disko Bay and deep along the Jacobshavn Icefjord to the Inland Ice. Everyone who met Max Dunbar here was, as I, taken by his ever compelling interest in and sensitivity to every detail of life and nature in this Arctic region.

As a very young man and a student at Oxford University, Max joined the 1935 Oxford expedition to Greenland ${ }^{2}$. The following text is his diary from that time, a very personal and lively record including his thoughts and ideas about life and many keen observations about the fine shades of human nature, animals, birds, mountains, sea, fog, light and dark, observations as subtle and captivating as could only be recorded by a person possessing a genuine love of life.

One could expect a scientist's diary to contain a string of dry notes and minute observations. This author is different. Max Dunbar is not only one of the leading scientists of our time but also a philosopher, a humanist and an artist. He lived in Greenland from 1941-46 performing the duties of Canadian Consul to Greenland and at the same time conducting research in oceanography and marine biology, disciplines which later gave him world renown.

Godthåb-Nuuk, April 1991

Svend-Erik Danielsen

Managing Director

The Bank of Greenland 


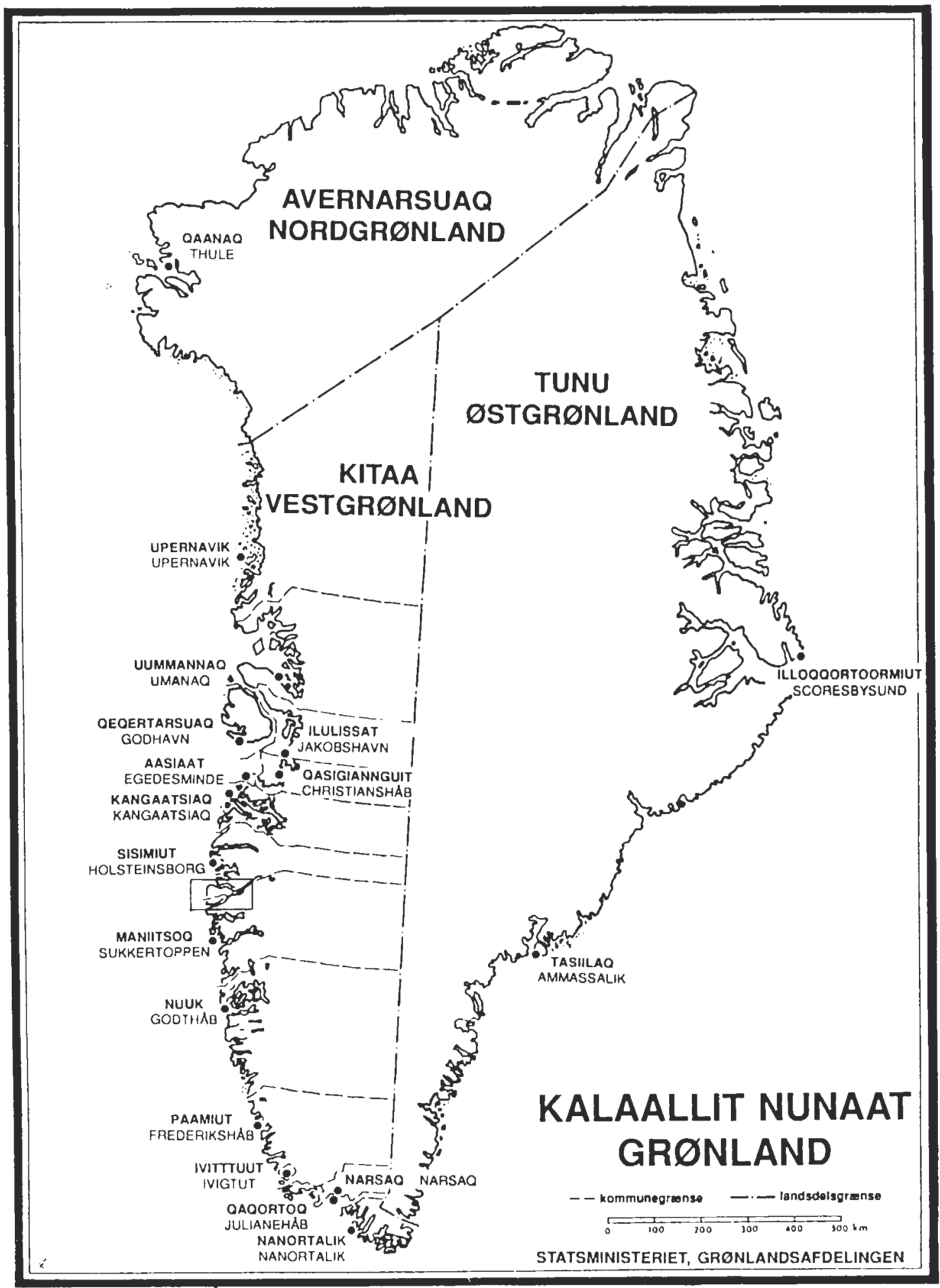

GRONLAND: LANDSDELE OG KOMMUNER 
$\mathbf{J}$ uly 8. Dannebrog.

Sailed yesterday morning at 9 . Saturday (the 8 th) we spent in Copenhagen. On Saturday night, after seeing " $M$ " at a cinema, we went on to the National Scala, to investigate Copenhagen night-life. The Scala bar was excellent, except for the pianist who played foul contaminous music and sang similar songs. He took half a second to reach each note, starting a third or so below. There was a Viennese ballet in another room, which was really worth watching. The girls were beautiful, and the men passable. They danced to Liszt's Second Hungarian Rhapsody, the Blue Danube, and something else that I can't remember. We crawled aboard at $1.30 \mathrm{a} . \mathrm{m}$., after the taximan had taken us round the town in a gallant effort to find the right dock.

We are now 26 hours out, and doing about 6 or 7 knots. The contrast between the Viennese ballet and our present surroundings is impressive. It is for me the highest price to pay for this trip that we are for the next three months cut off from music and feminine company. The touch of a piano would be very welcome even now, only one day out, and the thought of someone in Colonsay has a sting to it. One can imagine oneself as a small piece of steel pulled in vacillating directions by magnets that are the things in life that we love. I suppose it is best to let each magnet have its pull. It is in fact the only way to live, for Greenland, a Bechstein piano, and the aforementioned company which we will call "Lisadel," are for the moment obviously incompatible. There are other magnets in the offing as well.

But there is one very happy thing in this connection which has occurred to me; the essence of every pursuit which is worth doing is identical. Whether one is writing or playing music, finding pleasure in riding a horse, in climbing mountains, in sailing boats, or in distant journeying, the ultimate goal seems to me to be the same in each case, and to be closely bound to, if not identical with, the purpose of life itself. To be able to head for this goal in the company of Lisadel, and with her help, is the nearest that man can get to heaven on earth. Whether or not this is an argument for the retention of the institution of marriage I am not sure! I have as yet little idea of what "the goal" or "the purpose" are.

Besides ourselves, there are three other passengers-one named Holtved and his wife, and a youth of seventeen whose name Holtved told me, but which I didn't absorb. ${ }^{3}$ Holtved, whom I have christened "the Professor," is going on archaeological work near Thule. He has been out several times and knows Greenland fairly well, but I think this is the first time his wife has gone with him.

The captain is large and quiet, and doesn't talk much else but Danish. There are about 5 or 6 in the crew, including a cook and a youth with a scarlet cap (with thanks to Calverley) ${ }^{4}$ who produces our meals. The ship's dog, a small terrier with warts, completes the personnel.

To the spirit eternal of life

To the keeper of this world's end

$I$, an unbeliever

This token of thanks do send.

(etc.??) On the bowsprit, evening.

July 11 .

We should reach the Orkneys sometime tonight. The sea at the moment is like the millpond of legendry. We had a discussion today on greatness and progress. The opinions of the lay mind on scientific progress are as good entertainment as George Robey. ${ }^{5}$ Their ideas of science go no further than wireless and explosives, with a little medicine thrown in. It's the fox and the stork.

Evening. Fair Isle in sight, also part of the Sherlands. The sea is like a gently undulating skating rink.

July 12.

Big doings in Derry. I wouldn't mind being at the Dogleap' now. The sea is no longer like an ice-rink, undulating or not.

July 18, Thursday.

Notice the gap since the $12 \mathrm{th}$. These last six days have been utterly disgusting. We met a westerly storm. We were below practically the whole time in that filthy atmosphere of the 


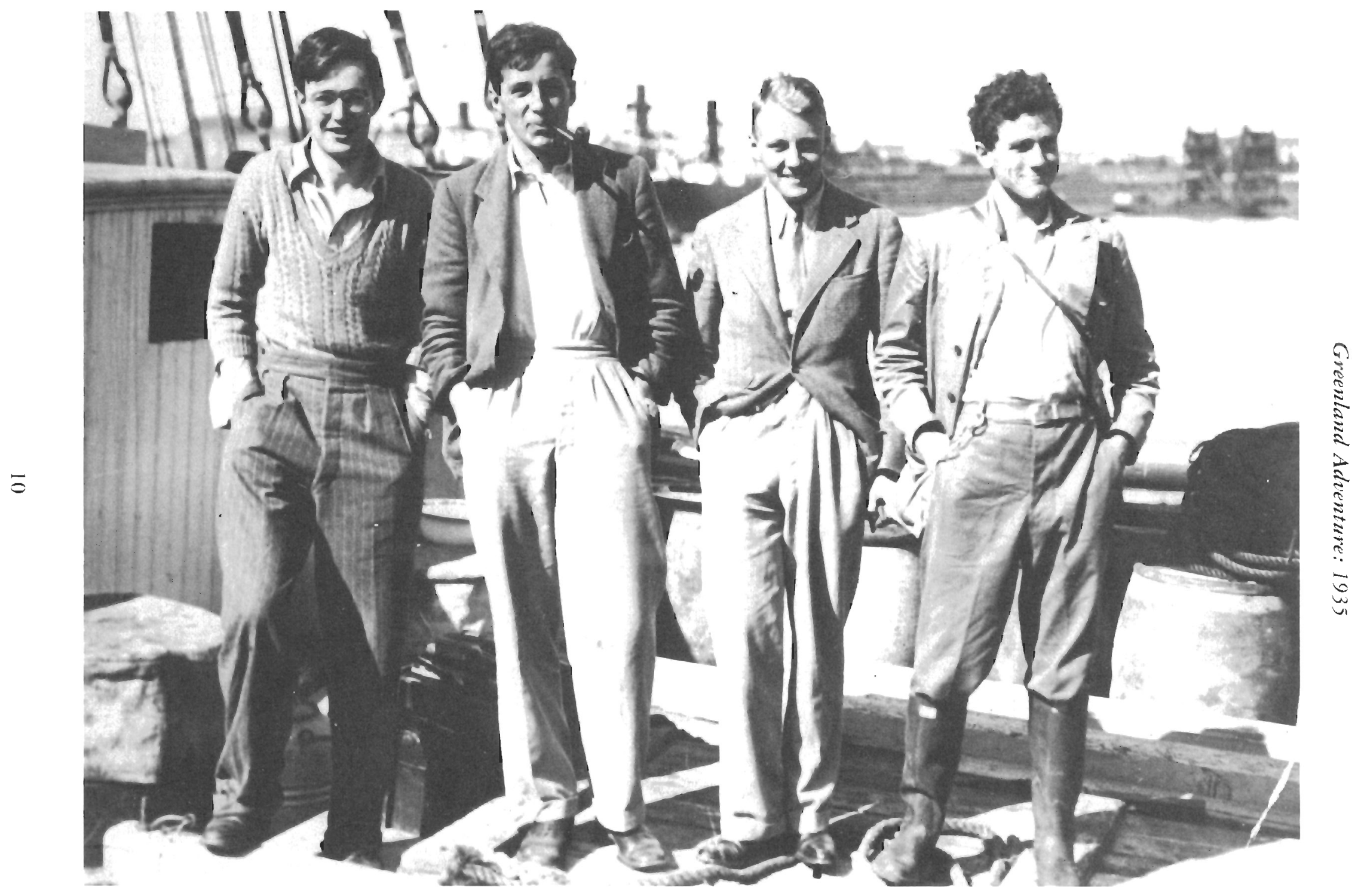

Figure 1. Copenhagen dock: Left to right-Henry Hayward, Michael Atter, Peter Mott, Max Dunbar. 
cabin, feeling like death. I was only actually sick once, but the constant knocking about by the ship's wild dancing was weakening, physically and morally. I kept thinking of all the lovely things I might be doing in Ireland, or at home in Edinburgh. They consisted chiefly of eating plain food. I thought of brownbread-and-honey teas, of apples, bananas, Brussel sprouts and chocolate. Every three hours the cook or his boy or both would come down in a hopeful sort of way and lay things for meals. The Professor ate solidly through the whole purgatory. The cook's pipe and cigars were another major discomfort. I have never smelt such vile tobacco.

Today is fine. The breeze is chilly, but out of it, it is warm. The sea is gradually losing some of the wicked looking mountains that it has shown for the last few days. During the whole storm we went north some miles, and forward almost none. Apparently the trip from Fair Isle to Ivigtut takes ten days in good weather. We left Fair Isle at midnight on the 11 th. We should be in Ivigtut about Friday or Saturday of next week, barring more storms, which God forbid.

Talking with Mike last night about little churches and pubs in the Cotswolds ${ }^{7}$ made me feel quite homesick, which is saying a lot for the Cotswolds. After one's recent treatment one is a fertile soil for such nostalgic sowings. The thought of Limavady ${ }^{8}$ made me wild.

July 19.

Made about 50 miles in the night. Not excellent going, but road-hogging compared with our recent speeds. The sea is getting a little more like an ice rink, with a slow swell. But the boat, with all her canvas down, is rolling like hell, as if she was doing it on purpose. The weather is beautiful.

Reading "The Evidence of our Senses."' A remark quoted of A. S. Eddington rather worried me: "We have found that where science has progressed the farthest, the mind has but regained from nature that which the mind has put into nature. From "Space, Time, and Gravitation," Cambridge 1921. This needs further investigation.
Washing just now is reduced to a minimum. My teeth are the only things that benefit in my system; so that we are now thoroughly greasy, whiskery and tousled, but getting suntouched and happy. It reminds me vaguely of Ballymaglin. ${ }^{10}$ And while thinking of Ballymaglin, those grand little pears will be ripening in a month or so, and the mountain must be lookin' well. I wonder if Aunt Nan is making any more Elderberry dye? The Roe, ${ }^{11}$ I am afraid, will probably be a little low, but I could get trout out of it all the same. And the Dogleap-porridge and cream, and gooseberries in the garden soon. I wonder who Aunt Dorothy is going to have there this summer. I have just remembered that I am scheduled to appear at Marble Hill in August. Something tells me I won't be diving into Harry's Hole ${ }^{12}$ this year.

Wednesday, July 24.

The weather turned cold again soon after the last entry. We had a "party" in our dining hall four nights ago. It began with hot rum punch and continued until about midnight on beer. The mate was very drunk and rather objectionable. None of us felt too well the next day. I hope to heaven we don't have another one; the cabins were almost unfit for a badger to sleep in.

The food on this ship is wretched. If it was really good, and British (!) I would be eating heartily, having got entirely used to the motion of the ship. As it is, yesterday's lunch came up immediately afterwards. It is the mixture of curious food and awful smells that destroys one's appetite. The table-cloth began to smell so filthily yesterday that we had to demand to get a clean one at once. We got it.

The cabin boy came down in excitement last night and reported that a whale had just passed. He said someone had photographed it. I wish I had seen it.

We should pass under Cape Farewell tomorrow some time, or perhaps the next day. We have to give it a very wide berth, because the ice gets packed around it, so we shall not be able to see land for some time. We should make Ivigtut by Sunday. If we manage a month in the Strømfjord area, we shall be lucky. 
So far, it has been an expensive trip. To pay so high for three weeks or more in this ship of smells-I think it goes by running way from its own smell--seems madness; I wonder why we do it. And three kroner a day for this food is wicked, even supposing we ate it.

The difference between the captain and the mate is that while the captain spits over the side of the ship, the mate spits on the bridge.

Friday, July 26.

Well west of Cape Farewell, but some way south. Stiff head wind last night. Today is nice. Clear and sunny, with a westish wind. The Professor was giving us advice about our tents this morning. He suggests putting on a strip of canvas round the bottom, to put stones on for wind. A good idea; we will probably do it in Holsteinsborg. It will, of course, add to the weight of the tents.

I spent two hours yesterday in happy recollection of a saucer-full of tinned apricots I had for lunch. This gives an idea of the kind of food we are putting inside us.

Saturday, July 27.

Going one point N of NW. Ought to be in Ivigtut Monday morning. The magnetic declination here is about $40^{\circ}$. On Strømfjord it will be nearer $52^{\circ}$. So that the compass just now is giving our course as due north. Today is cold, with no wind.

It is a good thought that we are going to the North Pole of the Winds; sort of watershed of the wind-system of the northern hemisphere. Small wonder we shall want those canvas skirtings round our tents!

Mike lent me a book yesterday from the Cambridge Miscellany; it was a small volume of the poetry of Charles Sorley. ${ }^{13} \mathrm{He}$ was killed in the war at the age of 20 . Some of it is good stuff. One particular couplet I remember:

"But I'll put custom on the shelf And let him find his God himself..",

Talking about his future son, which he was not destined to have.

$\mathrm{C}$ minor nocture.
$\mathrm{C}$ minor statement $\rightarrow \mathrm{B}$ flat major, with a simple tonic and dominant harmony over an octave or more in the treble $\rightarrow$ E flat major? $\rightarrow$ A flat major for the running bit, and then straight back to $C$ minor. I'm glad Jean ${ }^{14}$ likes what there is of it.

Evening. Going about 7 or 8 knots. Flat calm. West wind. Going almost due north. All canvas set. Fine. Played "Hearts" till late, with the cook. The cook won. He has a most suggestive way of cutting the cards, but it may not mean anything. The opinions seem to point to arrival in Ivigtut to-morrow night.

Sunday, 20th.

The West is Awake. Came up on deck this morning in bright sunshine. Cape Desolation looking like the giant's castle, and guarded by glistening icebergs. The sight is one to make the eyes water and imagination whirl. Through the glasses it looks like some fairyland of rock and ice. It is very cold.

Then came the mountains and the ice,

As though the mist, crystallized and cold from sleep

Had shed upon the day its gift of fairyland.

There's a sonnet to be found round that some day. The whole three weeks of rather grim voyage has melted away as if they had never been. The coastline is a prize worth waiting for.

The inland ice is also in sight, just south of Cape Desolation. Its dead flat horizon disappears into the sky, and it can be seen stretching for miles inland.

My beard is progressing. I spent some time this morning dry-shaving it and clipping it and generally exploring the methods of trimming it. I am quite determined to keep it till I get home. I wish I could grow more just below the lower lip.

Midday. Almost round the Cape (Desolation). There was a belt of fog turned up about 11 , but that has gone again and we are once more in the sun. What wind there is, and there is very little, is as cold as the ice it comes from, and it is really more comfortable 
Greenland Adventure: 1935

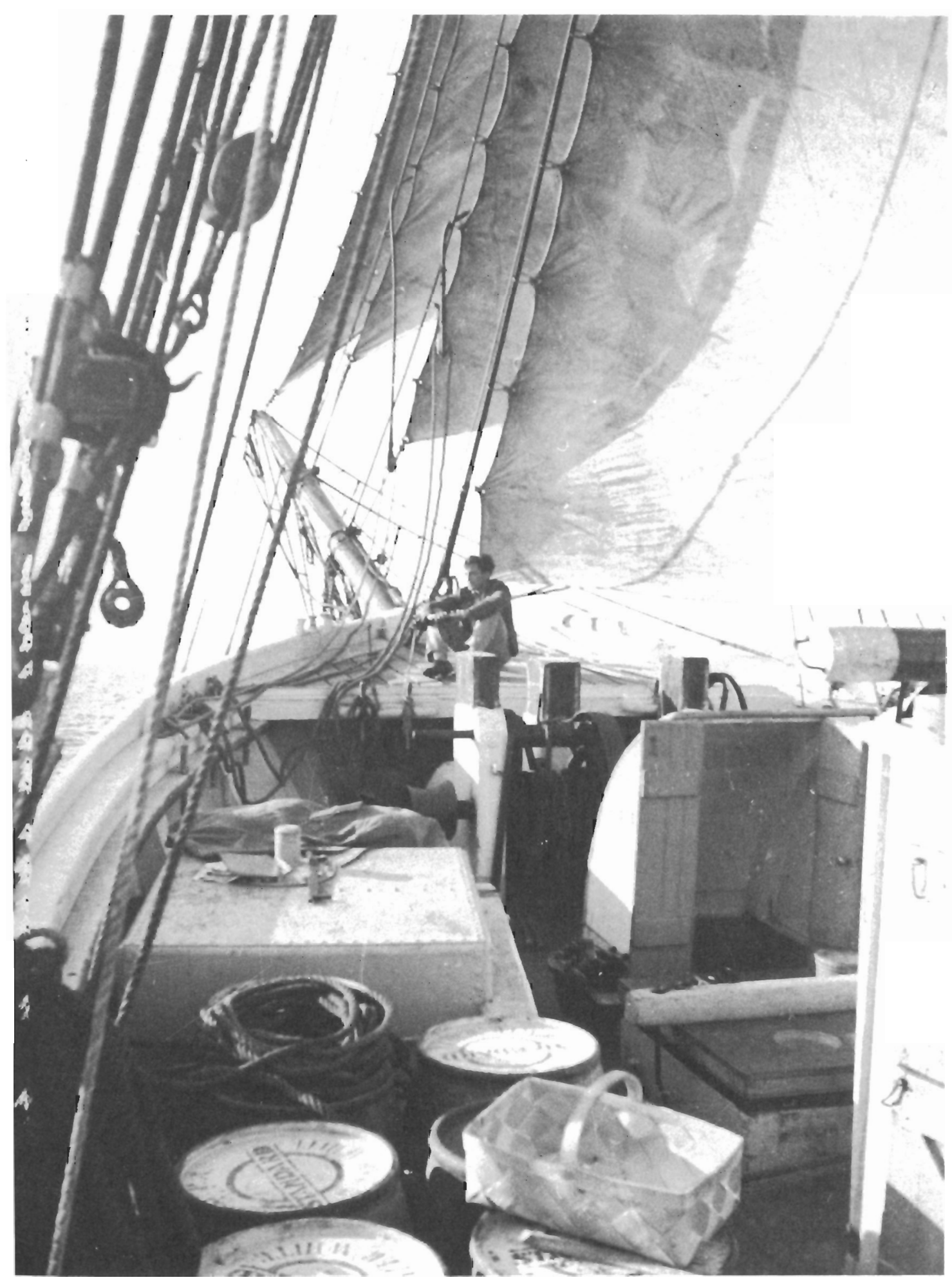

Figure 2. Mike Atter on board the schooner "Dannebrog." 
Greenland Adventure: 1935

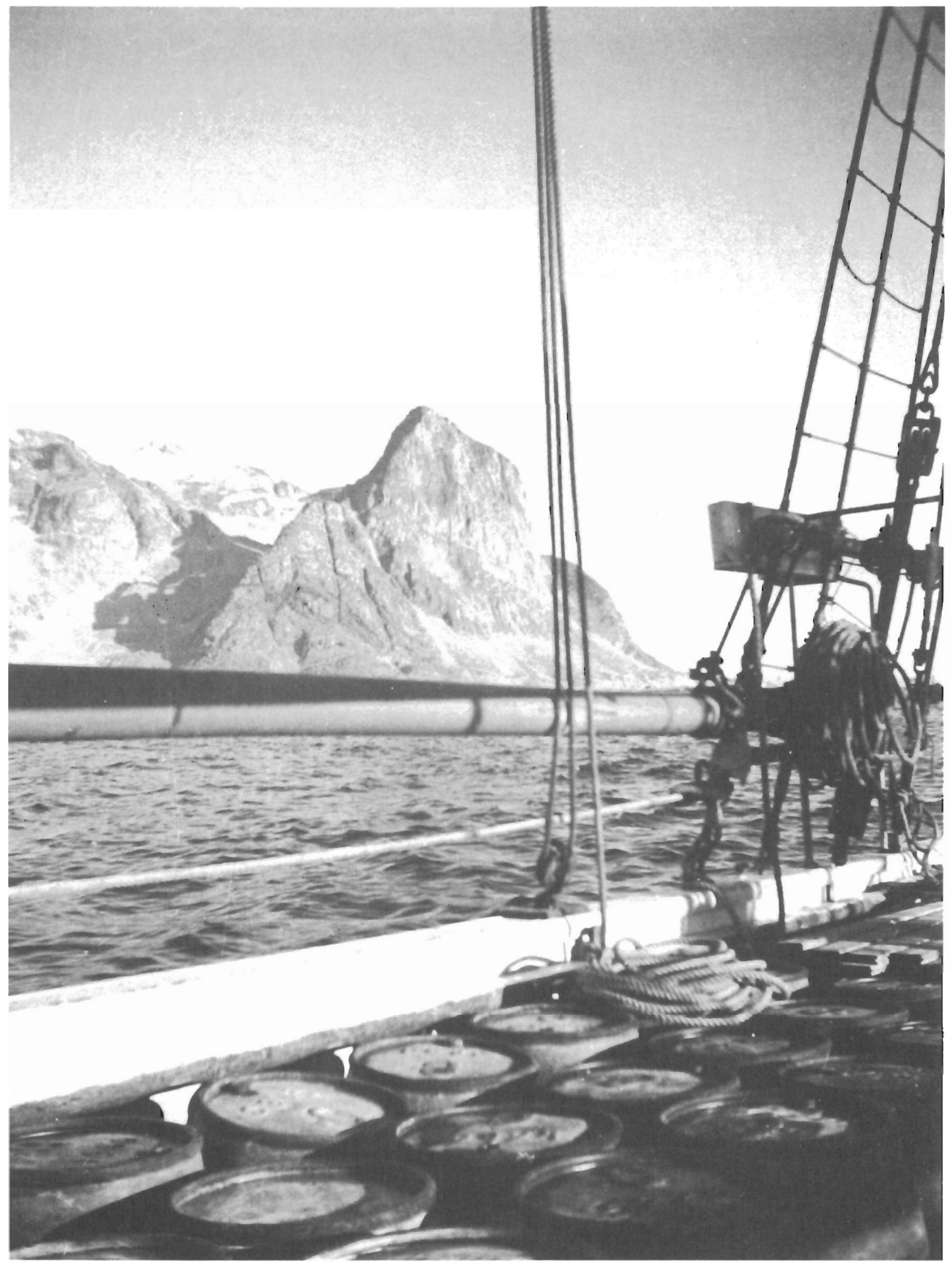

Figure 3. Cape Desolation, Southwest Greenland. 
down here in the cabin, where we have the stove going again.

The usual lunch has just gone by. We are hoping for a large store in Ivigtut and in Holsteinsborg, where we can get such outrageous luxuries as chocolate, chewing-gum and biscuits.

8 o'clock. We have just come round the island opposite Ivigtut. We are now in a narrow strait between it and the mainland. It is lovely. Dead still water, dead still sky. The sun casting some of the mountains into light, others into shade; a few small icebergs. The colouring is magnificent. We passed one little headland all ragged and rocky like the Rosses, others like bits of Scotland. Most of it is like the tops of the Cairngorms brought down to sea level and magnified. The cameras have been busy. I endorse Mike's feeling that if we turned straight back home now, we would not feel cheated.

The only life in sight consists of birds and jelly-fish. There are some small, dark brown, almost black, birds with white patches on the wings and white under the wings. They fly quickly and are partridge-like in flight. [Guillemots]

I should love to come here with Peter ${ }^{15}$ and a small sailing dinghy. Hovering round this coast and exploring the fjords would be good. And these mountains would be good climbing.

Jean's ${ }^{16}$ lamb-lined gloves are a great blessing. I shall certainly pack them in my rucksack. They have been admired by the whole ship's company. And they remind me of her. I have written her; also Moira ${ }^{17}$ and Ronald; we hope there will be a boat from Ivigtut before the "Disko."

After midnight. Went ashore. Arrived Ivigtut 9.30 p.m. Ivigtut centres on a cryolite mine, and consists of a number of rather nice little houses of slate (red) or wood and scattered over a rocky slope surrounded by a semicircle of hills. We discovered a mysterious pool of warm water, probably being the overflow from some plant or other. There is a steamer here, the "Elie," from Esbjerg, which will take our letters to Denmark. Further exploration in Ivigtut and surroundings tomorrow. Mike and I want to go over the hills, but Henry wants me as interpreter (in German), to go to interview the Governor. But as the Governor seems to speak perfectly good English, I shall try to persuade him that my services will not be required.

Came back aboard and made chocolate of cocoa, sugar, and condensed milk-dry brewed, ${ }^{18}$ in fact! Then up to the galley to make toast. Helgi (one of the crew) Leif and Manne Rasmussen were there too, and supplied with chewing-gum, chocolate, bread and butter, we passed a replete hour and a half. The Rasmussen boy is the son of the famous explorer, the Warren Hastings or perhaps Captain John Smith of Greenland. We have just learned from Helgi and Leif that there is an epidemic, apparently of chickenpox, in Holsteinsborg. This may seriously hold us up. I hope not. The Governor will be able to let us know tomorrow probably.

The night is still as Karl Böhm could have wished. There is a redness in the sky to the north. It is like a Chopinesque dream, though perhaps Grieg would feel more at home in these latitudes.

Wednesday, July 31 .

Left Ivigtut at 11 a.m. Monday was a very full day. Henry and Peter went to see the Governor and arrange matters at Holsteinsborg. Mike and I went up into the hills. We didn't get far, partly because we were told we would sail at mid-day, but mostly because our training was foul. We could hardly move at first, but we got a little better later on. The flies-black flies-are very annoying, but the veil deals with them effectively. They don't worry one's hands so much. There were not many mosquitos about, but we are expecting more at Strømfjord. Vegetation: Blueberries, and another darker berry, with a lot of seeds, quite good to eat [crowberries, ed.]. Myrtle, and a kind of shrub willow. A little creeping spruce, or something of the sort, is found higher up. Coarse grass. Mosses of various sorts. No ferns.

This is the only cryolite mine in the world. $\mathrm{MgAlF}_{2}$. I kept three specimens of it. They were loading up the "Elie" the whole time. 
There were a number of snow buntings, lovely birds. The flowers were not in vast abundance, but there were some. A large purplish flower that I don't know (as I don't know most flowers), coltsfoot, a sort of double coltsfoot, and a few smaller flowers of Alpine aspect complete the list.

We ate our bread and sardines and rushed back to get to the boat in time, to find that no one had dreamt of sailing yet. I broke H.H. (Hans Huber, my Alpenstock) on the way. There was a cliff to climb down, so I chucked the staff to the bottom. When I went to retrieve it, the iron spike had come unstuck. Pity. In the afternoon Leif took Mike and me in a small boat he had the run of by some means or other, and we went along the shore a little, landed, and climbed another hill, higher than this morning's effort. Leif is worth his weight in gold. He can produce practically anything out of the cook, or the bowels of the ship, and is very willing to do anything for you.

Supper of fried hake at 6 . Very good. Then a bath!!! What a bath. They have a sort of communal bath house above the workshops, and we emerged looking quite new. I made my beard look no end Byronic, or Browningesque. We donned our party clothes (a tie) and went ashore to the Mess, the place where all the engineers and their wives feed. There we sat down to a table laden with an overgrown hors d'oeuvres, beer, and Snaps. Curious meal, but very merry company. Followed by coffee, brandy and whisky in the lounge. By this time I was feeling pretty good, and in my newly-trimmed beard talked sparkling German to the ladies.

The doctor-Faderspøl-(I think) ${ }^{19}$ is new here, but seems to be pretty well known and liked already. He is a funny Teutonic-faced man and is usually laughing. Reminds me slightly of Dr. Reuter. ${ }^{20}$ We showed him round our ship at midnight, and then returned to his room to play the piano and sing. It was good to get a piano again, though it was not in the best of tune.

Danish songs are rather angular and sudden. This is the one they sang most: (A flat major: "Slaa Rommen i Glasset.")
The next house of call gave us beer again, which was bad. We sang some more, danced and did various tricks-a little unsteadily, Holvved was there, and he was very drunk. I danced an impromptu Irish jig, a sword dance, and my exhibition of the Russian school. Peter and Mike did some gymnastic stunts which I couldn't face at that hour.

Wandered back aboard about 2 a.m., dawn just showing itself. My bunk was strewn with my possessions, so I slept across four chairs till 8 o'clock (Tuesday).

Feeling very shaky. Sailed 11. Was very painfully sick at 6 , and got rid of a quantity of poison, I should rhink. Slept well, and today I am feeling myself again.

And this is exploration. Well, well. Some whales have been seen. They look like large porpoises in the water.

I gather it takes 4 days from Ivigtut to Holsteinsborg. That means landing on Saturday. Strømfjord, we hope, by Monday.

Evening. I have begun the downward path. I am learning bridge. So is Henry. But for this trip only; I shall forget it on landing in Leith, ipso facto. It takes far too much thinking. Just now I have cut out in favour of Leif. I think Henry wouldn't mind any if I cut in again on him (Henry).

Land in sight again. The coastline looked rather fine just a few minutes ago, with the evening sun on it.

Someone in Ivigtut made the remark that he expected war in Europe within six months. I don't know why this remark should worry me more than many similar ones I have heard at home, but it did. I am not quite certain what my reactions would be if war came again. I think I should be so despairing of the quantity of common sense in the world that I would just not worry about life any more. War is such a shockingly impersonal affair that I cannot imagine any person feeling obliged to fight. He would, it seems to me, be so certain that if he had a say in the matter war would not have occurred, that he would feel bullied and shanghaied if asked to fight. The only thing that would persuade me to fight would be the arrival of an aggressive nation 

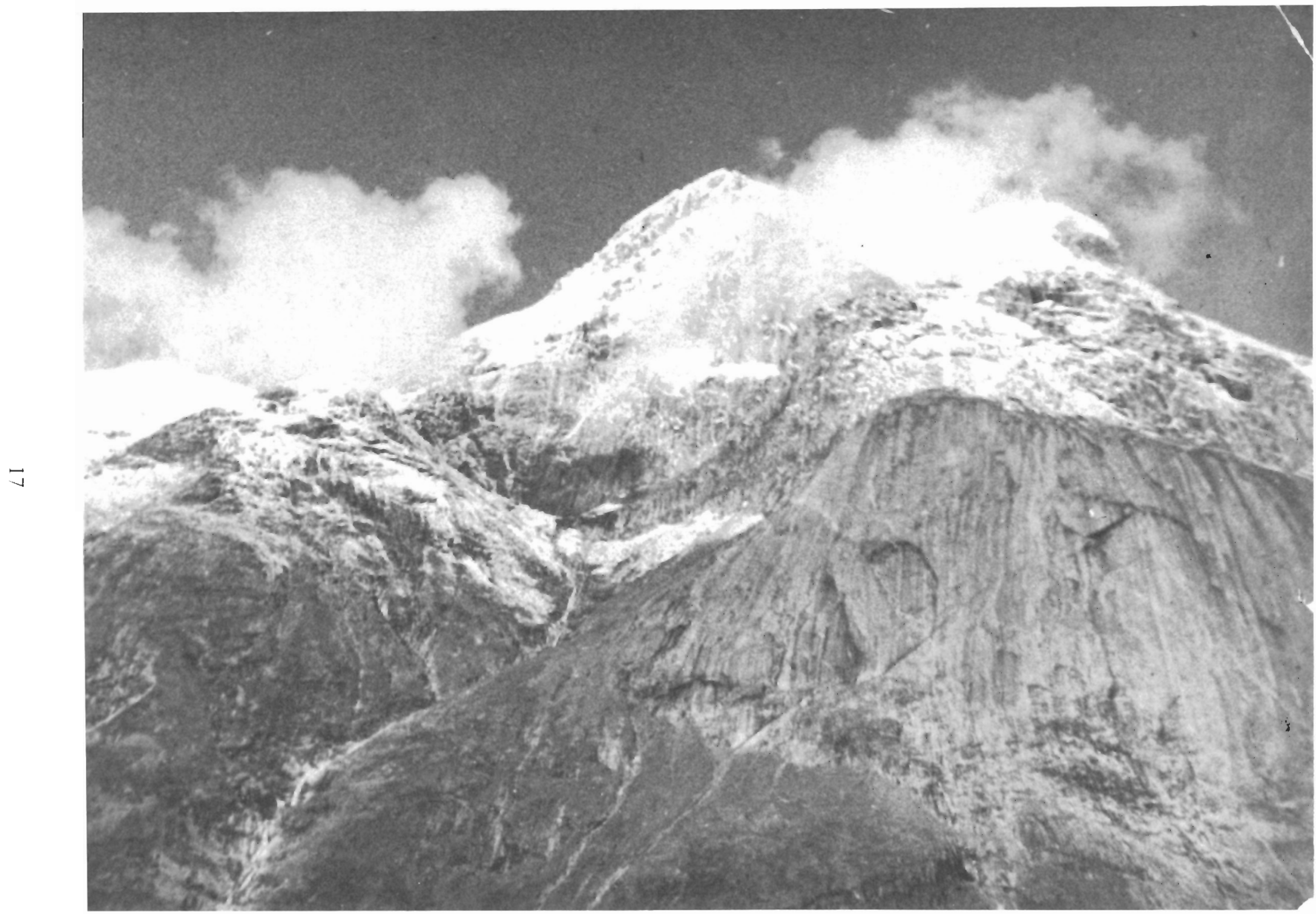

Figure 4. Kuunaat Mountain, near Ivigtut, Southwest Greenland. 
saying "We want all your colonies and all your possessions." It seems to me that several nations would be quite justified in asking politely for a share in some of the British colonies, particularly those with vast areas of uninhabited land. In the days of smash and grab we grabbed far too much.

The world would feel safer if it was certain that its diplomatic and political affairs were in the hands of its most enlightened citizens. Meanwhile I know that thought and art are the most important things in life, taken in their most wide sense, and that "the Preachers" are the men to follow. But how to convince others?

Thursday, August 1.

Opposite Godthaab. Began setting "When I was one and twenty" by Housman to music, recited to us by Henry. The coastline is still finer now, and the mountains higher. Henry was rather worrying today with his expounding of what he calls his "drill" on arrival at Holsteinsborg, and Strømfjord. I forgot to laugh (to myself). Mike said at Ivigtut that it was only by laughing to himself that he could stand Henry's goat-like efficiency. He is rather like an old duck and keeps on quacking periodically. But I certainly admire his enterprise in doing this trip, having done no climbing or camping whatever before.

Old Holtved is rather impressed with our appetites at this stage of the trip. He was quite flabbergasted when we passed around hotbuttered toast immediately after supper tonight. We made it at the stove. I think his opinion of the capacity of Britishers is going up. Anyway he and the Captain and Fru Holtved were too surprised to accept any toast, which was all to the good.

Peter has been having great difficulty with his insides lately. They just refuse to work. The scientific packing with dynamite that we have been putting him through is the cause of much amusement in the camp. He produced a little "Vegetable Laxative" labelled "1 to 3 at bed-time as ordered by the physician," so the physician (myself) promptly ordered the full dose. As he has already absorbed two spoonfuls of Castor Oil, he has no excuse. Calomel comes next on the list.
Friday, August 2:

Very little progress in the night. We met head winds, and today we are sailing along westwards instead of northwards. Just now (lunch-time) we are within 200 miles of Canada and heading straight for it. We are rolling fairly heavily and it is very cold on deck.

Saturday, August 3:

Mike's twenty-first birthday. Twenty-one on Davis Strait. It may be possible to celebrate this evening in Holsteinsborg. We should get there about 4 or 5 this afternoon. The wind is much less today, but it is still cold. I think the slightest breath of wind on this sea makes it very cold. If, by chance, we don't arrive in Holsteinsborg till tomorrow, it is likely we shan't get our stuff unloaded before Monday, as the crew have a holiday on Sunday in port.

Sunday, August 4:

Arrived in Holsteinsborg last night at 8.30 or so. The mate started unloading at once for us, so I was up on deck checking boxes with Henry. The A and N [Army and Navy Stores, ed.] have been rather difficult in their numbering, and we had to have four counts (one by each of us) before we were satisfied we had everything. The Greenlanders came out in flocks of rowing boats, and grinned amiably while we bustled with activity. They were very helpful, and behaved like kids with our rucksacks, dancing about on the lighter with them on their backs. The stuff was stowed aboard the "Nakuak" at once, by the good offices of the Governor, Mr. Rasmussen (no relation), who invited us to coffee afterwards. His wife makes the most marvellous cocoanut cakes; I am afraid I let myself go over them, but I expressed my appreciation of them. She also played some early Tauber ${ }^{21}$ records, which were good; he sung the Lieder as Lieder, and not to show off himself. I must remember to look out Schubert's "Nicht Klagen" (Kam der Tag).

We are invited to lunch today with the Governor and his wife at 12.30 .

Last night we slept on shore, in a sort of wooden hotel with nobody in it but ourselves. I tried to sleep for half and hour, but couldn't, 
so I got up and dressed very quietly (Mike never stirred) took my camera and investigated the surroundings. In the town, while taking a photo of a Husky pup, I heard a voice behind me say "English;" there were four people behind, all Greenlanders. One of them, a small boy, came forward and pointed at the camera, so I took his photo, to the general delight. He then squeaked something which I told him firmly I couldn't understand. I think he expected the picture to appear at once for him.

The view inland was good. I spent 4 or 5 exposures experimenting on sunlit clouds, then watched the sun come up. It was a fine sight. The highest wraiths of cloud turned golden at first. Then the colour came down through the clouds till it lit the peaks of rock, and finally the sun lit me.

Slowly came the dawnings

For it's light the whole night through;

But at 3 o'clock o'mornings

There's a kindle in the highest sky

And ......

Glitters suddenly in song

The Governor opened the store for us. Three of us got weatherproof "jerkins." I bought a spare pipe, probably American. And we got the canvas for the tent skirtings. Each of us has a different theory of the interaction of tent and wind and its circumvention, but Rasmussen says the wind in the Strømfjord area is not great.

We are to be picked up again by the "Nakuak" on the 31 st of August. Not much time. Henry is probably staying on. Big money speculations this morning.

\section{Monday, August 5:}

We saw off the "Dannebrog" yesterday from Holsteinsborg, 7 a.m. They gave us breakfast on board. Henry and Peter and I went down to a group of men working on a drain (at 5 a.m.) mentioned "Dannebrog," and immediately two of them shot off for a boat, rowed us to the "Nakuak" for our washing things and the whisky for the mate, and on to the "Dannebrog." We gave them some cigarettes, and away they went happy.
Many farewells. We went back to shore with the Greenlander watchman, whom we christened "Whiskers" (we have a photo of him) and watched the "Dannebrog" sail away. She looks splendid when one is outside of her.

We stopped on the way here (Strømfjord) to have coffee with one of the Geodetic Institute lads surveying the coast. He has a very nice little ship, Kelvin-motored. He dipped the flag for us when we left.

Now we are chugging up Strømfjord. Just breakfasted on porridge (good, but we didn't make enough), biscuits, butter and cheese, capped by a little tea. The biscuits we pack are wonderful. All wholemeal-digestive, wheatmeal, oaten. The sides of the fjord are all rock. We have seen the ice-cap in several places. There are deep, dark seams showing horizontally in the lighter "ground" rock. I wish I knew more about geology and petrology.

Mike and Henry are landing soon at Sarfartok ("the Place of Much Current") to prospect for a base-camp. Peter and I are bound for Hobbs' $\$ 1000$ dump-heap, ${ }^{22}$ returning probably tomorrow. Then the "Nakuak" leaves us.

Evening. Landed Mike and Henry at Sarfartok, 1 o'clock. There was no book of words packed with the Klepper, ${ }^{23}$ and we left them struggling with a forest of struts and stays. Went on to the top of the fjord in the "Nakuak." Landed at 9.30 at Camp Lloyd. Went straight to Camp Evans, 3 miles due east. Here we found the shed locked securely, though Rasmussen had said it and Camp Lloyd were open. The lock fixings were so rusty that we had to break open the door. The first door I have ever broken open. It was closely followed by an inner door which went the same way; but it was much stronger, and I almost concussed myself charging through it. We ransacked the place. It was full of lovely things. There was a beautiful .39 Winchester Repeater; it was hard to have to leave it behind. We found one of his (Hobbs') precious radiotrons, though what use it will be to him, God knows. It is at least six years old and must be hopelessly out of date.

The walls were hung with pictures of "Miss Atlantic City" and similar stimulants. I shall 
Greenland Adventure: 1935

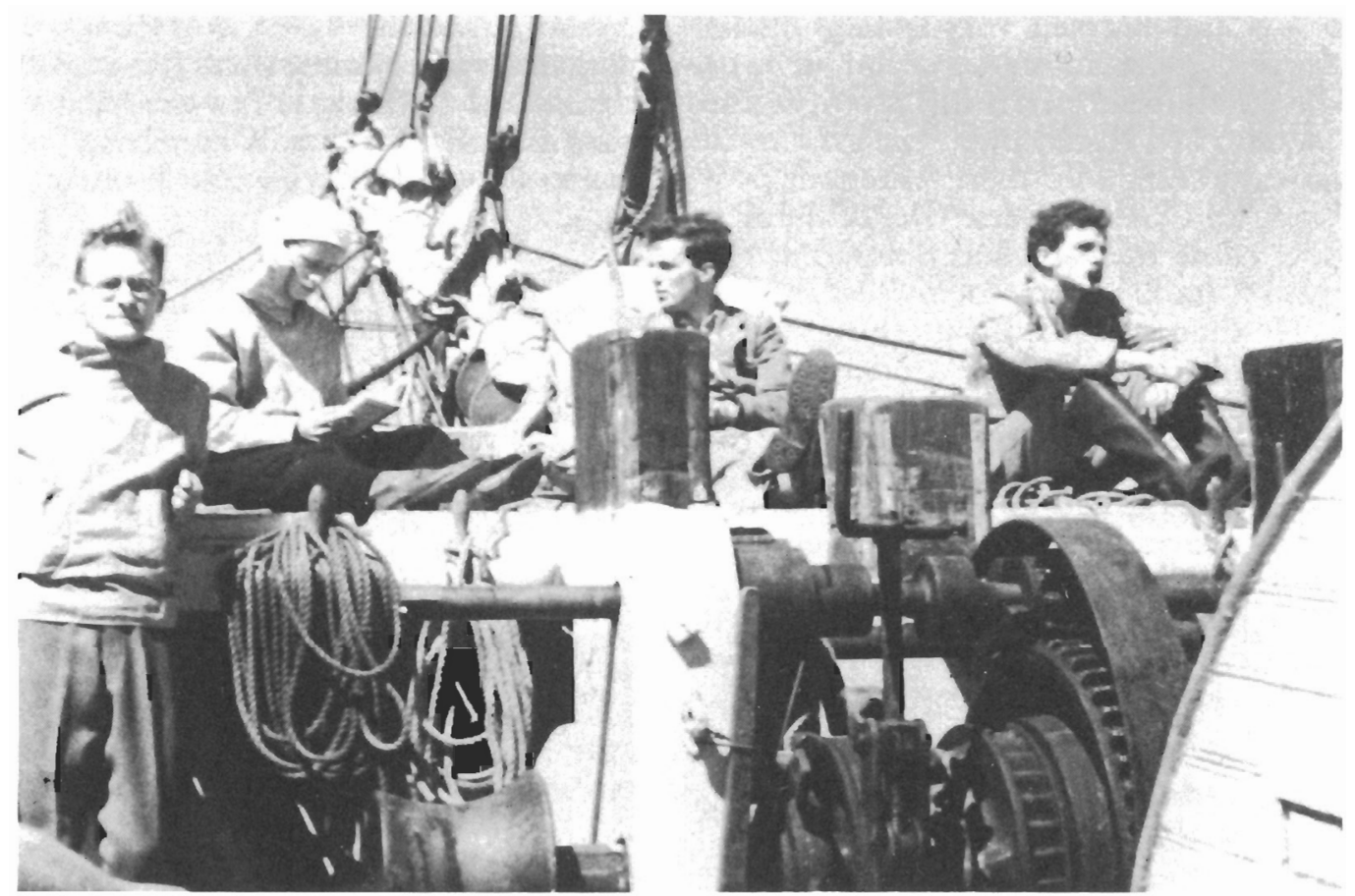

Figure 5. "Dannebrog": Left to right: Professor Holtved, Manne Rasmussen, Mike Atter, Max Dunbar.

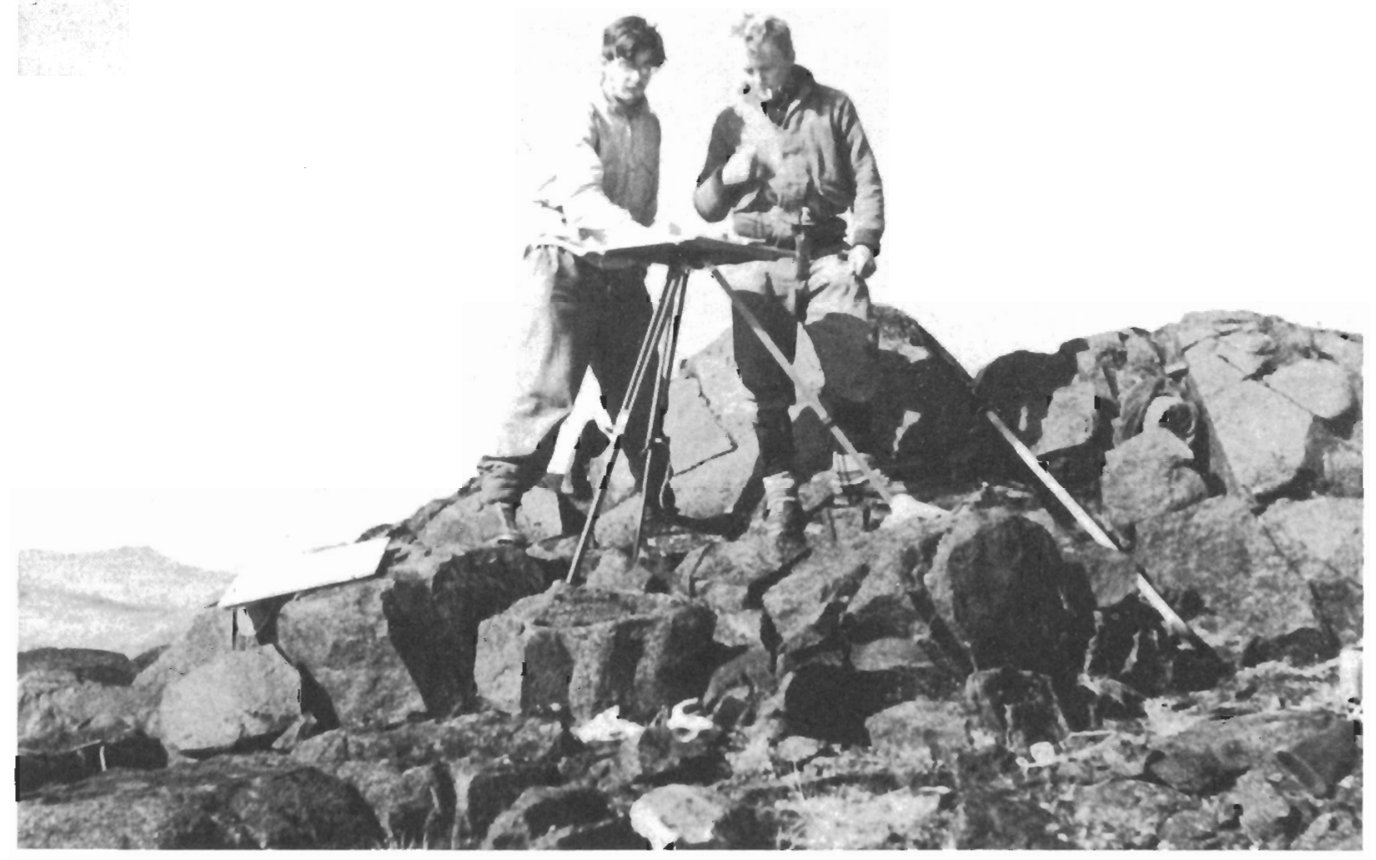

Figure 6. Henry and Peter at the survey job. 
see that they are sent back to him. Found a toy trumpet.

Back at Camp Lloyd. Peter was very tired by this time (1.30, Tuesday 7 th). We had got into the Greenlanders' skulls that they were to come for us in three hours from 9.30. We were an hour overdue. We yelled to the "Nakuak" anchored about a mile along the coast. Not a sign of life aboard. Peter went to sleep under a caribou skin. Went along the coast. Yelled for two hours intermittently "Ahoy Nakuak." Lit a fire to amuse myself. Greenlanders all sleeping like cats, casual blighters. Arrived for us at 9 a.m., grinning. Woke Peter. Sarfartok $\rightarrow$ landing stores $\rightarrow$ shallow water. Klepper and no sleep. Up river with Henry in Klepper, found site for base camp on the other side.

Base Camp pitched (I forget the day and date). This is now August 13 th and a Tuesday, if my reckoning is correct. Base camp has been here about 4 days now. Henry and I reconnoitred a Klepper route for depot-laying inland. $\mathrm{He}$ and I went up to Heel Plateau (so-called because all our heels were hurting). Three days ago we started from our little camp up the river at 6 o'clock (up at 4.30 a.m.). Three and three-quarter hours up (3500 ft from sea level climb), and ten and a quarter hours working on a base line at the top, and two hours down to our camp again. Here we opened our first tin of pemmican. We parked "Theo" (our theodelite) and instruments, etc., there, and went on light to the base camp. Arrived midnight. 17.5 hours up and going most of the time, was just enough. We were greeted with sighs of relief by Mike and Peter, and a magnificent hoosh. ${ }^{24}$

Today (13th): Blood sports-Mike-rifle. Depot laying by the other three. I went up to Teddy Tarn, packed up Pemmican Camp and dumped the stuff opposite the waterfall, where it is to be picked up (they are camping there tonight and tomorrow night). I began investigating the population of Teddy Tarn. Sleeping base camp, alone, taking rations to the others tomorrow, and going on with the tarn. Results published later, no doubt. My heel is sore, and there is an inkling of that damned big toe trouble again. Going over the scree $^{25}$ to the tarn is rather uncomfortable.
There is the hell of a lot of scree around here, avalanche and moraine.

\section{Wednesday 14th August.}

Last night was beautiful, and today there is not a cloud in the sky. I am writing this beside Teddy Tarn, the inhabitants of which are probably and justifiably feeling a trifle neglected.

I enjoyed being alone in Greenland last night. I would like to camp here for weeks. This morning I brought some food to the river for the others and dumped it beside Theo, etc., which had not yet been picked up. The others were on the other side. Henry and Mike came across in the klepper. I saw Peter moving off with a carrier (Everest carrier) in the direction of the food dump, looking as if he had done enough back-packing for a long time.

The plan is now: Mike, Henry and Peter are to fetch the ration cases from below which they hadn't time to fetch yesterday. That will mean 6 cases at the waterfall. I am to stay here for the afternoon, to collect water animals. At 6 , Mike is coming here, and he and I will go back to the base, to return tomorrow with pemmican, chocolate, some rations, instruments, and my own kit. We then klepper food up as far as we can towards "The Island," 20 camp there tomorrow night, and return the day after for more. Meanwhile Henry and Peter are going to go up to Snow Peak and survey. So far, so good. There is so much to do that days keep getting slipped here and there, and original plans have had to be modified.

Coming across that damned scree this morning I started a young avalanche going. My heel didn't benefit by it, but I think it is going to be all right. This tarn is in the middle of a sort of "unfinished landscape" of moraine and general "slag-heaps." One side of the moraine is quite like the arid desert of Asia. See photograph, provided it comes out.

Mended my rucksack last night at the base. Why the devil can't British manufacturers copy the Bergen decently? The workmanship is wretched. Anything that can come adrift, comes. 
Thursday, 15th.

Mike and I are now in camp on the sand beside the only stream we could find. We snugged down the Base Camp this morning, packed very heavy packs full of pemmican and chocolate and rations to the waterfall. Two hours or more going. And it was warm work. That scree for the last time for 10 days at least, thank heaven. We kleppered five ration cases and our rucksacks, paraffin ${ }^{27}$ and rifle one and a half hours worth up the river this evening. We ought therefore to dump 10 days' rations, and a large quantity of pemmican and chocolate at the Island tomorrow. Henry and Peter are to meet us there at 8 p.m.

It is going to be a push to make the lake ${ }^{28}$ in the time we have, but it would be good to do it. Henry, of course, considers it no use unless he can actually survey it. Personally, I think just to reach it would be fine. But I am no surveyor. Mike agrees with me.

I am very glad it is Mike who is the other non-surveyor. He is the only one who is what some people call "sympatisch." $\mathrm{He}$ is interested in many things, and with him it is possible to talk and think at the same time. Henry talks of nothing but surveying or plans; "shop," in fact. Peter ${ }^{29}$ is charming but I am not sure how much he is enjoying himself. To be working inland into entirely unknown country like this is a thrilling thing to be doing. If we could live on the country it would be better still, but the only possible food available is hare and ptarmigan. We hope to get some soon. Also small berries of unknown name. The only signs of fish so far seen have not been encouraging, and we are not packing fishing tackle, to save weight.

I like thinking of all the things that are likely to be happening in the places I know while we here are completely cut off from them. The Dogleap will probably be having sunny weather. Moira is there and probably Bep, ${ }^{30}$ in her dairy-coat. Everything going on so beautifully poetically and in such a business like way. ... The river will be low, and Bob Holmes working miracles. There will be bathing and picnic parties, at which C... Thompson will be talking as loudly as ever, and Eila ${ }^{31}$ as quietly. And everyone laughing.
The best place on earth. At Dunfanaghy ${ }^{32}$ it will be as boisterous and free as ever, though one of the party will never be there again. I wonder whether Mr. and Mrs. Cochrane are really over the worst. Perhaps they aren't there just now.

Where Henry (Havergal) ${ }^{33}$ is, God knows. In Scotland probably, fishing. Tight lines to him. And here, this night that never comes, and a silence so vast that it hums.

Friday, 16th, 2.45 p.m.

At mid-day today we upset the Klepper. Every damn thing was soaked and I was above my waist rescuing the boat. I didn't have to swim. Nothing is lost. All our garments are gradually drying. It is an ideal day for drying things. "It might ha' been verra much worse." The only trouble is that Henry and Peter will not find us at the Island tonight, supposing they are on time themselves, which is doubtful. I think they have enough food with them. It is really rather funny. We have saved the precious matches, and the rifle is now none the worse for its swim. The adventure will probably put us back a day. The Island certainly looks a long way away still.

Saturday 17 th.

MIKE WAS DROWNED TODAY. I shall have, I suppose, to make a complete statement of what happened later on. Here, suffice it to say that he died by jumping in after a tin of paraffin. I spent a ghastly hour and a half looking for him and then went to find the other two. We can do nothing about getting the news through so we are for the moment forgetting about it, beyond searching heavily. I stuck his ice-axe in at the place he leapt in, with this epitaph:
"It was too beautiful a day
for him to die;
He did so love the light,
so love the wind,
so love the rocky sunniness."

More of this later probably. At the moment I have much to adjust.

Sunday, $18 \mathrm{th}$.

I find that after yesterday I have contracted a physical lethargy, though not a great one, 
and a desire for intense mental effort. I would like books on such subjects as scientific philosophy, music, or even algebra. It is the best way of making the picture of yesterday become "ground" and not "figure," which is the first step towards pushing it into the background. Have been in camp all day, since crossing the river to join Peter and Henry. They have been out searching for Mike and getting food. They want to go on surveying for a few days, before making for the base camp. Myself, the sooner I see the base camp the happier I will be. I have the Browning here to read.

One of the first thoughts that came to me yesterday was of Mike's Anne Morrison, and the next was of Jean, and the thought of Jinny was like the opening of a door.

Monday 19th.

$9.30 \mathrm{a} . \mathrm{m}$. just woke up! This is to be a slack day in camp. I changed the site yesterday to a nice little hollow, more sheltered than the last site. We had a fire last night, told stories and sang songs around it.

Tuesday 20th.

Noon. Starting shortly for the Island! Crossing the river, picking up some food, and camping two nights at the bottom of the hill. This is probably our last mountain before going back to base camp, via the waterfall camp. It has not been easy to carry on, and I shall be glad to see the base again.

... 1.15 p.m. Henry, who had the coliwobbles this morning, was sick and didn't recover in time; we are here for another day. Henry is lying in his tent.

These slack days are just the thing for us in the circumstances. It gives one time to think of pleasant things.

4.15. Have just been around the next two bluffs towards the Island with Peter. Hoped to see my pair of hawks, but saw no sign of them. I think they look like Peregrines, but I am not sure. So far as I remember, Longstaff's expedition ${ }^{34}$ recorded no hawks in this area. I have recovered a bit now, sufficiently to think of "something lost behind the ranges" again.
Had some target practice with Peter. The target was a piece of toilet paper tied to a stone. I smashed the first stone; the second time we used so large a rock that a howitzer wouldn't have scratched it. Good shooting. The range was 40 yards. Henry is a little better. He has somehow managed to get a "chill." He says he may be able to manage some Julienne soup for supper. There must be something wrong when Henry is off his eats.

Wednesday, 21 st.

Henry has recovered. We left camp at 12.25 , crossed the river, collected food, and made for the Island. Peter's performance in fording Clearwater River, or the Cherwell, 35 as it was afterwards called, was very good entertainment. His language on reaching the other side raised the temperature of the surroundings considerably. He would insist on going a way of his own, knowing, I am afraid, just damn all about rivers. There was the same kind of moss on some of the stones in the river bed as grows in the Roe in abundance. It was good to see it. It will never let you slip, no matter what you have on your feet.

Henry is tired now, after his bout of yesterday. Early start tomorrow, up the Island. Arrived here (Clearwater camp) 6.35. Now 9 o'clock, and sleep for me.

Thursday, 22nd.

9.15 p.m. Been up the Island. Pretty sticky climb up, but not too long. Lovely on top. Went away by myself while the other two started plane-tabling. Sunny. Came back. Henry and Peter weren't finished for 5 hours (4.30 p.m.) They are rather entertaining to listen to together. Henry: "The Admiralty Chart put this hill 10 miles from the fjord." Peter: "What, the Island?" "No, this one we're on." "Oh." They were on the Island! And so on.

Way down, (scree). ${ }^{35}$ Camp-fire. Very fine hoosh. Getting windy; hope the tents stand up. Tomorrow we start back for the base. Snow on mountain tops. Clearwater Valley. Promised Land. Ravens; two caribous, remnants of; hoof.

Friday, 23rd.

Left Clearwater Camp. Crossed the river (Clearwater) at a different place, to please 


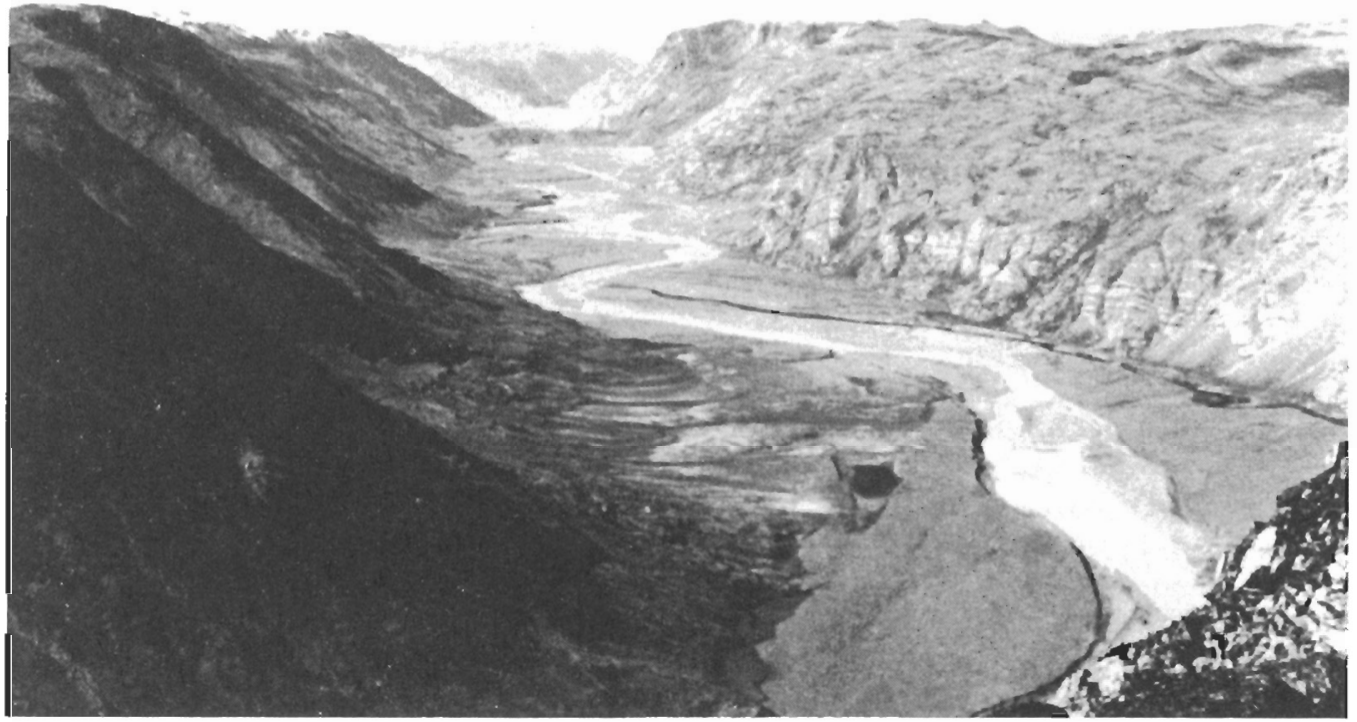

Figure 7. Sarfartok River (Kugsuak), looking toward the Inland Ice.

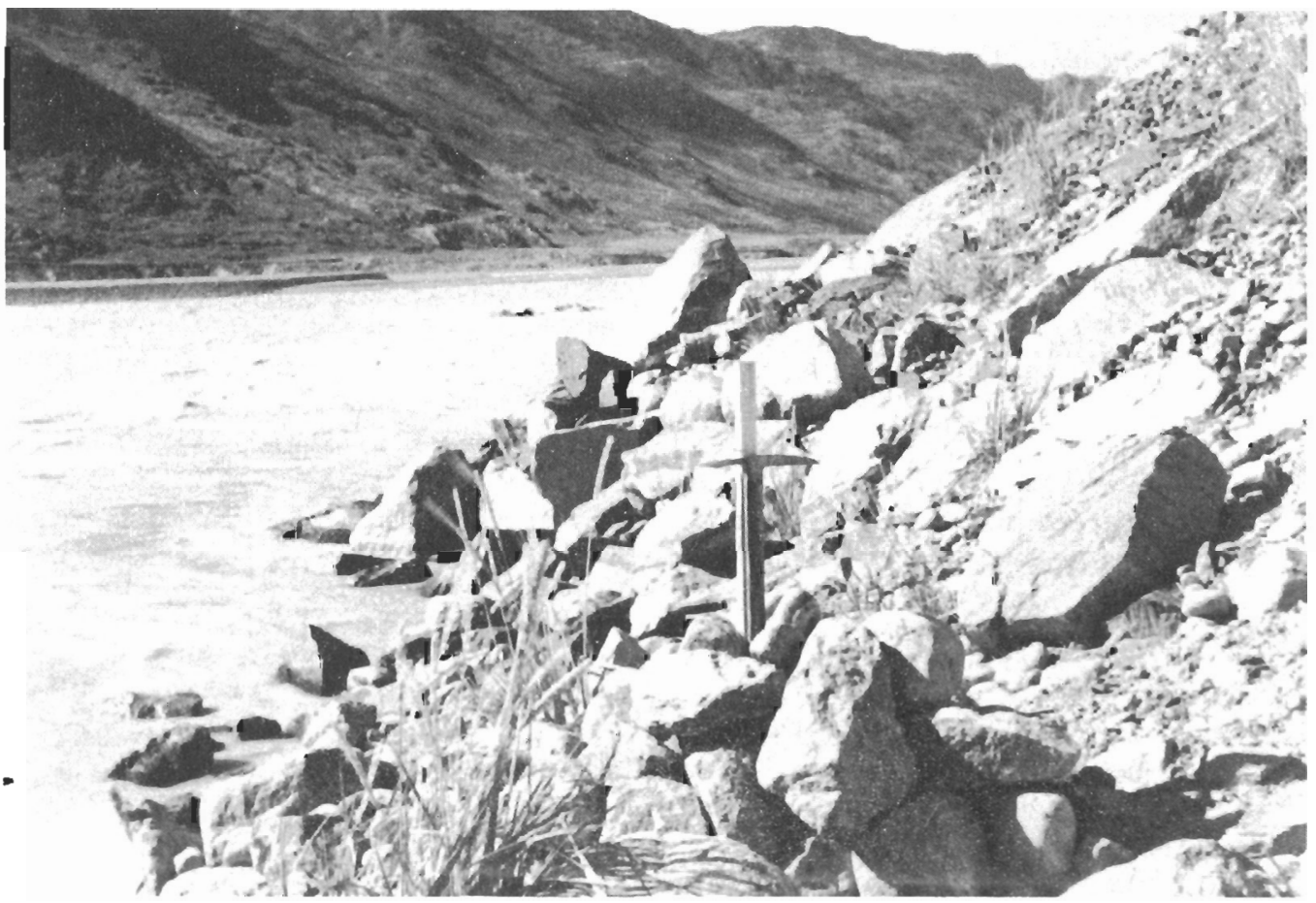

Figure 8. Mike Atter's ice-axe, at the place he drowned. 
Peter. Made the crossing of the Sarfartok River at the spot below the scene of the accident for the last time, thank God. Now (8.45) in camp, about an hour from Snowy River. Tomorrow we fetch the stuff from Whitestones Camp, and the Klepper.

Thoughts on the march-overbearing men: Arctic hare, Cold; Beginning of way back. "Willie" stopped today; Peter forgot to wind him, (Chronometer).

Saturday, 24 th.

9 a.m. Going back today for the kit and things at Whitestones camp. I am doing the Whitestones camp. It is getting colder now at nights, and there is usually a good deal of mist to clear away in the morning. Getting autumnal, in fact. I saw an eagle yesterday; looked quite like a golden eagle, but I didn't have the glasses with me. Perhaps I shall see him again.

7.15 p.m. Same camp as yesterday. Everything gone as planned. Tomorrow we sleep at "Snowy River" camp. I think tomorrow afternoon I shall do a little bird-watching. Henry and Peter are going up the side of the waterfall to do some plane-tabling.

There was an illuminating thing happened today. That dear old duck, Henry (I am not so sure about the "dear") is not a born leader. Leaders are never self-appointed. Peter is very fond indeed of cheese. We are running short of it here, and there was a tin at Whitestones. Peter begged me not to leave it behind, and Henry pooh-poohed it and quacked out a "list of things in order of importance," adding "bring the cheese if you have room." Actually the load I had was very heavy. But if I had asked Henry what was the most important thing in it he would have said, I suppose "the theodolite." Whereas any damned fool, provided he knows how to lead expeditions of this sort, would have known that by far the most important thing was Peter's cheese.

It has not been at all easy to keep a grip during the past week. I was over most of the shock after the first three days, but even now I find my thoughts wandering near the edge. To find oneself in the delightful process of making a new friend, a real friend, only to have him snatched away under one's eyes, is not pleasant. Mike would have been one of my nearest friends, I think.

Henry has just produced a typical, beautiful remark: "I don't believe in thought."

Sunday, 25th.

9.30 a.m. Misty rain, and cold. A decided change in the weather. Just packing up.

1 p.m. Cloudy, but no rain. Snowy River Camp set. Henry and Peter have just left to their plane-tabling. I am going off soon (when this pipe is finished) with the binoculars to look at birds.

I am getting a little tired of Henry. Next time I come on an expedition I shall either lead it myself or make sure I know the leader first, and approve of him. To have an asentient old goat like Henry as nominal leader tries one's temper. His pompousness, or "pomposity," is unbelievable. I rather think that the leader of an expedition should be considerably older than the rest of the party.

6 p.m. Saw eagles again. Pair of them. They are drab brown in colour, lighter, and mottled, on the breast. White fetlocks. One of them, I think the male, has a lighter patch on the top of the head (sea-eagles). I watched them for an hour this afternoon.

Saw the base camp. Both tents standing. Came back feeling a little colywobbly, so went to bed. The others are back now.

I begin to appreciate Peter better. He has a funny way of looking at things. I can see that he, too, is not sure of his approval of Henry, but he is far more polite and mild about it than I could ever hope to be. He just doesn't let it worry him.

Monday, 26th.

12 midnight. It may even be Tuesday. We had an explosion last night at Snowy River. I exploded. Peter did his best to make it smoother for Henry, while backing my arguments at the same time. Only Peter could do it. Anyway, Henry was told just where he got off. He was very apologetic about it, saying it was "just his way." The thunder cleared the air a great deal, and we returned to "Shaftsbury Avenue." 
Today we came back to the base camp, taking the stuff down in two loads and Kleppering across. The Klepper is standing up well, but it has had a trying time, and it is a bit strained in all its members. We made the base about 6 o'clock, taking things easily. Tomorrow we hope to get a little cleaner.

My tent was standing perfectly, which was good, but when I opened the door I found a young lake in it. That is the Greenland way. My kit-bag was also considerably moist. Another day like today will soon dry things. Supper of canned beans and tomato, apricots, biscuits and jam, and tea. Hot lemon last thing. Pity there were no baked beans left. We must get some more from the food dump. They are much better than the canned ones.

We were discussing what we should leave behind here. I find I am like the sandy-haired owner of the yacht in the "Riddle of the Sands." 37 I love chucking things overboard and am leaving as much as possible. Peter is just the opposite, and gets worried if we leave a tin of butter at a camp.

Tuesday $27 \mathrm{th}$, about 6 p.m.

Breakfasted this morning at 11.30. Done almost nothing all day. Began skinning my caribou hoof, but stopped when I cut my thumb, to let it heal before I went on with it. Made a scale model of the dimensions of the tent I am designing. Read Browning. The book I have is the Tauchnitz volume 2, with "In a balcony," "Dramatis Personae," and "Dramatic Romances." He has some good things to say, but most of the subject matter could better be expressed in prose.

It has been overclouded, windy and cold today. Yesterday was beautifully warm and sunny, and still. It is as though the summer was wondering whether it couldn't last another week or two after all. We decided it was too cold to worry about Kleppering across for food delicacies, such as onions and potatoes, and tinned fruit. I hope the wind keeps itself under control. My tent won't stand a storm just now.

Discussion on social service this morning at breakfast; Terrier and Boys' Clubs. ${ }^{38}$
Henry is outside contemplating the infinite. He seems a little introspective today. I think he is rather haunted by the accident, a thing which I am trying hard to avoid.

Wednesday $28 \mathrm{th}$.

$10.30 \mathrm{a} . \mathrm{m}$. Just had breakfast. We are all feeling shockingly slack. This afternoon Henry and I will take across the first gentle Klepper-load.

There is a sudden spate of enormous bluebottles. A fleet of 5 of them has just zoomed into the tent, leaving a 6 th as sentry outside.

8.30 p.m. Just came back from a Klepper party, with Henry. Next step to Piccadilly.

Thursday 29th.

11.45 a.m. Last night we read Kipling in turn. I wish we had brought some more decent literature. O. Henry would go down well, and I wish I had taken Jean's advice and packed Emerson with me. Peter and I are going to take another Klepper load across, so as to leave only two more for tomorrow.

5.30 p.m. Back from Klepper trip at 3.30 . Henry went fishing for a short time, but caught nothing. Not surprised in this filthy water. Feeling very slack. Henry and Peter mapping in the big tent. I have returned to my bag to get really warm. They are going to wake me when the supper cooking starts. Fried potatoes, mealy puddings and beans tonight.

10. p.m. Bed. Tomorrow we clear out of this camp and go and roost on the other side until the "Nakuak" turns up. One can't take risks with the casualness of Greenlanders.

Friday, 30th.

About 6 p.m. (?) Started packing up the base camp this morning, to cross to the other side. I was standing doing nothing for a moment, when the thought came to me "The Nakuak might be there already." So I went round the corner, and there, a little dot on the fjord was herself. This demanded instant action, with our experience of Greenlanders, so Peter and I shot down in the Klepper, boarded, and took a good grip of them. I had a moist and muddy job getting the Klepper back to the base camp. Henry had packed up, 


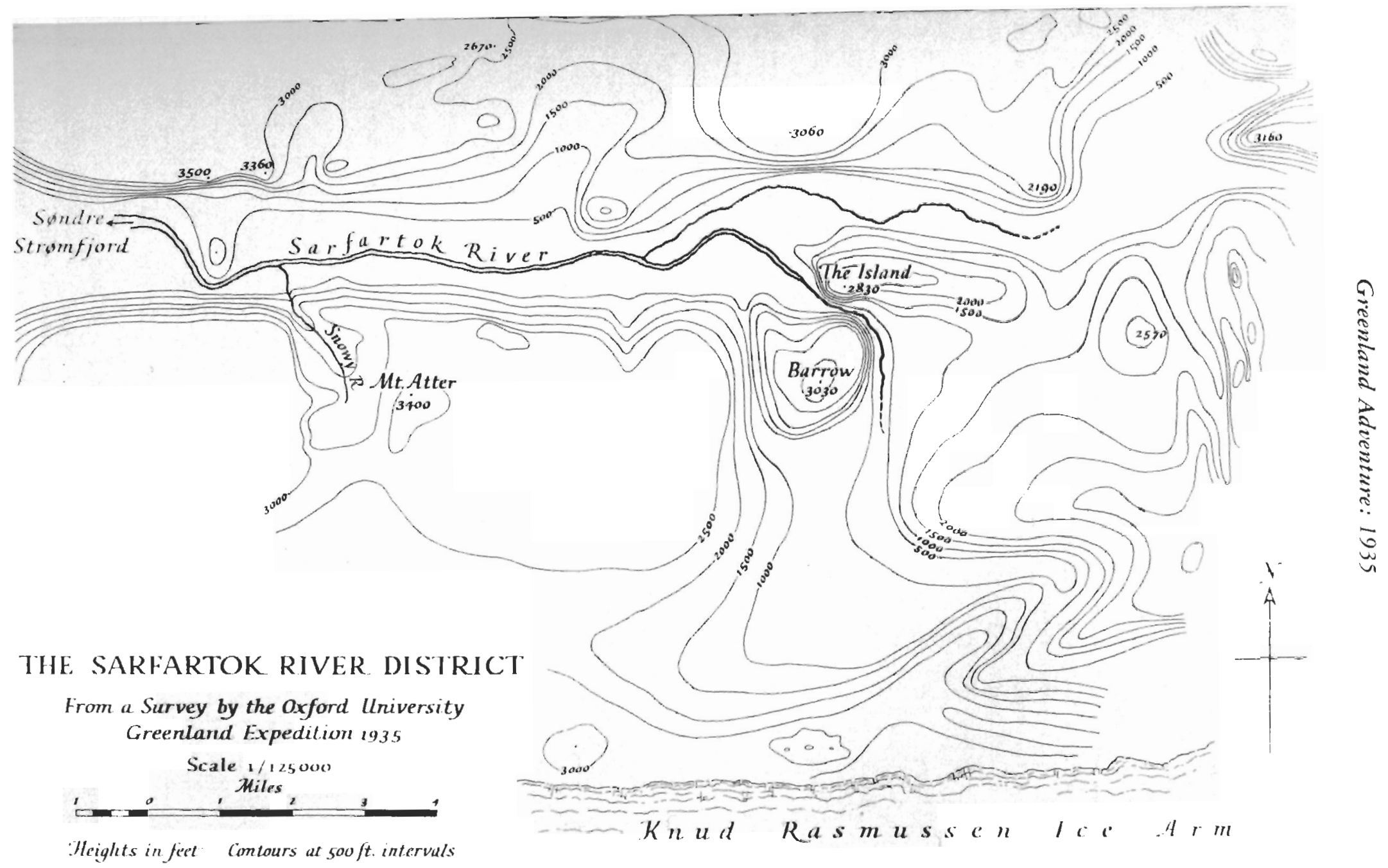


so we took the last load down, and said goodbye to the base. The tide had fallen a bit, and the sand-flats gave us some more wet towing. But we made the "Nakuak," and went ashore, to find Peter and the Greenlanders with their boat high and dry on the mud!

Henry and I, wet through and very cold, gave Peter our remaining dry clothes to keep him warm and returned to the "Nakuak" with the "Captain" in the Klepper, changed and got warm again. We are now below, just waiting till the tide has risen enough to let Peter and the other two Greenlanders bring the last load of stuff aboard.

Saturday $31 \mathrm{st}$.

12 noon. "Nakuak" anchored last night in the little inlet opposite Sarfartok, a darling litthe creek. Had some comic entertainment last night watching Peter putting up his bed between the two boards down here. It was piled on two bully tins, one board from a food case, and a piece of hold hatching. It was very funny, but it worked.

Heard the engine starting early this morning. Time unknown. Our last wristwatch has broken, and "Willy," who has already stopped twice, is our only timepiece. We have to add 4 hours and 5 minutes to him to give us local time.

The Greenlanders don't agree with my "overboard" tactics. They shipped five extra food cases yesterday. They will be in larder for months. We have just had a photograph parade, much to the Greenlanders' amusement. After it was over one of them made signs of drawing to me and pointed to the wee chap that I had tried to sketch on the way out. I showed him the picture, and they all chuckled with glee.

Henry is at present shaving off his beard with the hair clippers from Mt. Evans [page 19]. Getting clean again is going to be a big business. I believe there is a bath on the "Disko," but we have to get tolerably clean before that, for the benefit of Rasmussen and his household.

11.15 p.m. Itivdlek. Anchored for the night. "Werry Nice" arrived just after us
(Geodetic vessel; see p. 19). We asked him to supper, and found when he came that he had already had a big meal and was pretty sleepy. We felt it was the best way of giving him the news of Mike's death. We leave tomorrow at 5. Holsteinsborg I suppose about 8 or 9 .

\section{Sunday 1 st. September}

Arrived Holsteinsborg mid-day today. "Werry Nice" arrived soon after. Henry went ashore to send the cable to Max Nicholson ${ }^{39}$, and brought back the news that the "Disko" is due to arrive on Tuesday and sail on Wednesday. We are now settled in our former digs. There was some pretty work getting us here. The entire populace of children helped to carry our stuff here. I saw one carrying the end of a rope that trailed from a box that another was carrying. A nother young spark marched proudly along with the lid of a saucepan. Both these kids belonged to the captain of the "Nakuak." The Governor is ill just now, and in bed.

\section{Monday 2nd. September, night.}

Last night a Greenlander boy arrived in the dead hours and produced a muff made of two bird skins, plucked of the outer feathers. It was wonderfully light. I bought it, or traded it, for Jean. It cost me a quarter pound of tobacco and a pipe. What with the quarterpound I gave to our gang of porters yesterday morning, the tobacco supply is going down.

This morning we took Mike's private stuff up to Rasmussen after Henry had listed it. It is to be sent home through the Styrelse, ${ }^{40}$ registered. He said: "Greenland has taken many men."

I went on up, or rather into, the valley behind this afternoon. It is lovely. Henry and Peter began drawing the map. Shave and wash; also lovely.

Tuesday, September 3rd. "Disko".

Snow Bunting

Redpoll

Lappland Bunting

Ptarmigan

Peregrine ( 1 pair)

White-tailed Sea Eagle (1 pair) 
Greenland Adventure: 1935

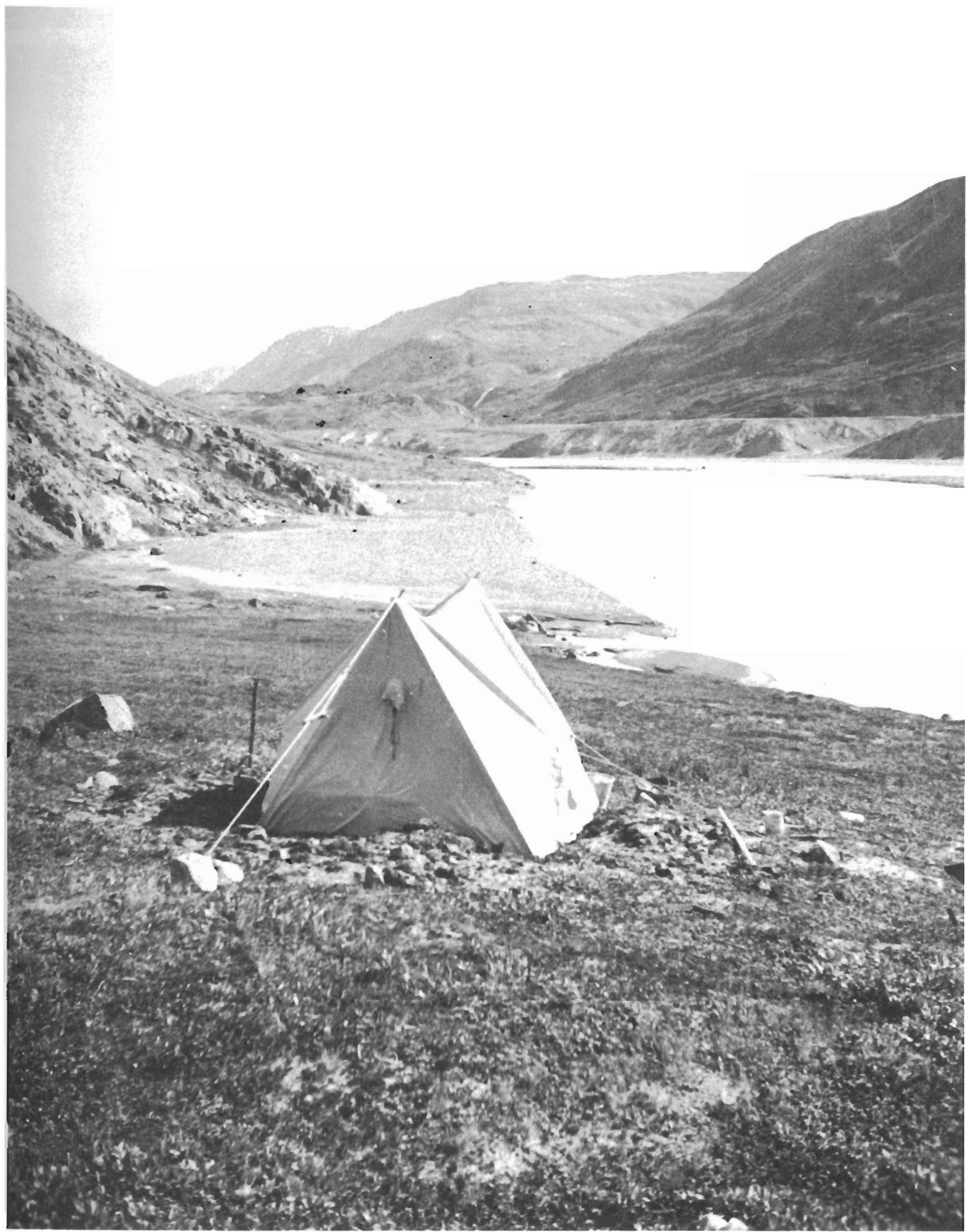

Figure 9. Sarfartok River; camp, looking upstream. 


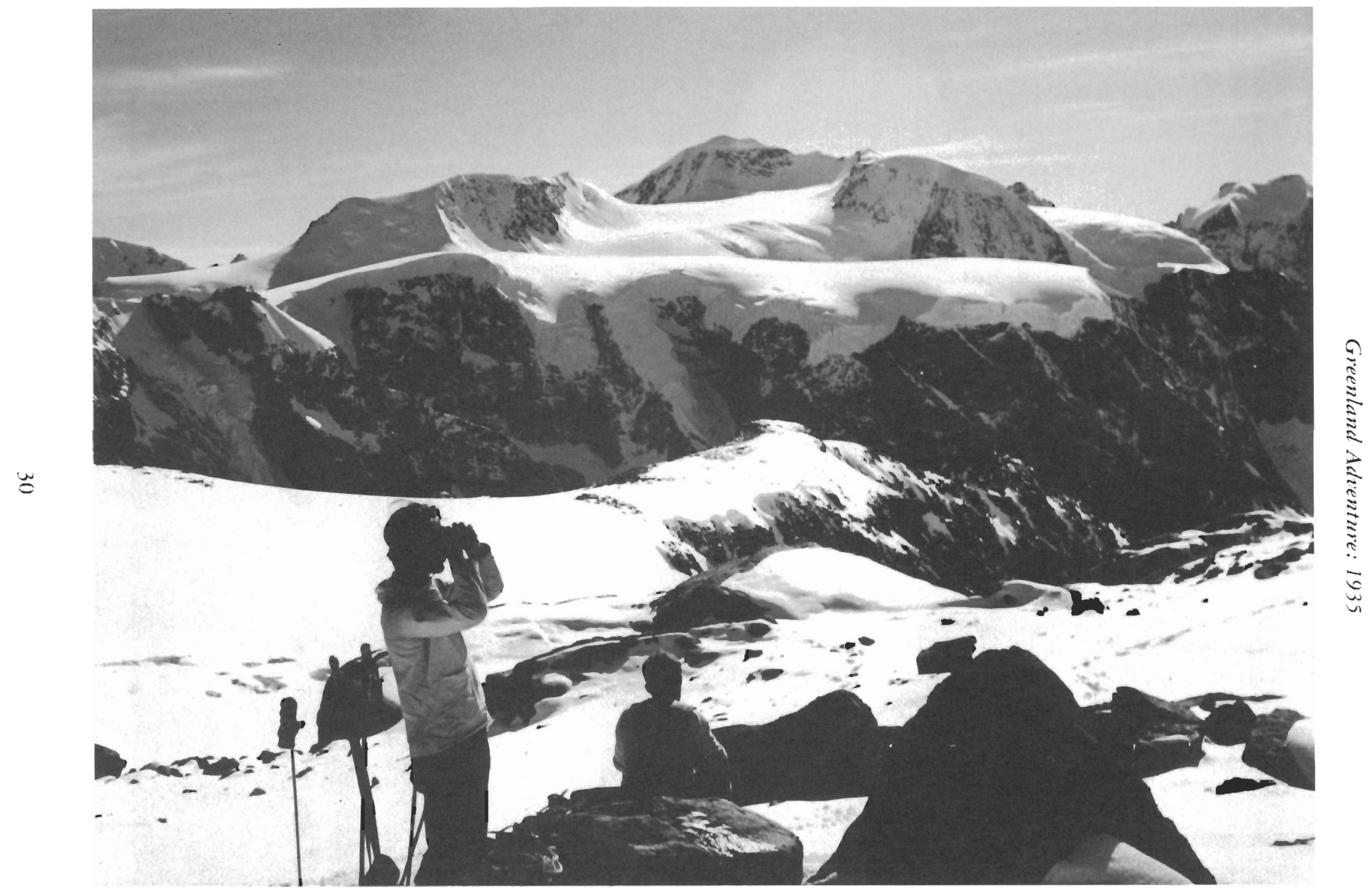

Figure 10. Mount Atter, named for Mike Atter, taken from Rasmussen Ice Cap. Photo: Peter Mott. 
You remember how the sudden mountains came

As though the misty vapours of a nightless Arctic dawn

crystallized and cold from sleep

had shed upon the day its gift of Fairyland.

And you remember how we spoke of climbing them;

Of that sharp gully, and the col, and that great sloping face

Cut by the dark basaltic streak.

And you remember how the sun at midnight, lulled to a glowing red, Climbed down the clouds again, Leaving a singing spoor of gold. Rest then, your grave is in a happy land.

\section{Notes}

\section{Biographies of the four members of the Oxford University Greenland Expedition 1935}

Michael Atter: Neither Peter Mott nor the author (MJD) know much of the life of Mike before the 1935 expedition (nor of the preexpedition career of Henry Hayward, below). Mott writes (in litt.) "I really knew very little of Michael Atter. He was not an easy person to know and tended to keep his inner being to himself." I (MJD) got to know him fairly well on the expedition, as my diary records. He was very athletic and a very thoughtful man. Of his plans for his own future he said that he had really none at that time. He came from Yorkshire, and I met and stayed with his parents on more than one occasion after my return to Oxford.

Max (Maxwell John) Dunbar: was born in Edinburgh, Scotland, in 1914, and was educated at Merchiston Preparatory School, Dalhousie Castle School, Fettes College, Edinburgh, and Trinity College, Oxford. Awarded a Henry Fellowship to Yale University, 1937-38, working on marine protozoa, he finished that year with an expedition to Glacier Bay, Alaska, with a fellow Henry Fellow (Wallace Brigden), in the summer of 1938. While at Oxford he served as President of the Oxford University Exploration Club and took part in two student expeditions to West Greenland, 1935 and 1936, the first of which is the subject of this memoir. The 1936 undertaking, with Christopher Hartley, was marine in scope, covering studies of the plankton of the region of Ata Sund and a pioneer investigation of the mechanism that forms and maintains the ice-free regions at the faces of tidal (calving) glaciers, which are not uncommon in polar regions, and are ecologically significant. In 1939 and 1940 he was an invited member of the Government party on board the Hudson's Bay Company supply ship "Nascopie," working on the zooplankton in the regions of Lake Harbour and Clyde River and other points on the ship's route. On finishing his PhD degree at McGill in the spring of 1941, Dunbar was taken out of the COTC, in which he had been training with cavalry 
(horses and all), and sent by the Department of External Affairs as Canadian Vice-Consul, later Acting Consul, to Greenland, completing three tours of duty at Godthb and elsewhere in the years 1941-42, 1943-44 and 1945-46. Joining the staff of the Department of Zoology at McGill University in 1946, he has remained at McGill until the present day, as Chairman of the Marine Science Centre (later Institute of Oceanography) and member of the same until its dissolution in 1987, and finally (postretirement) with the Climate Research Group in the Department of Meteorology. Sabbatical years took him to the Greenland Fisheries Research Laboratory in Copenhagen, the Smithsonian Institution in Washington, and the British Museum of Natural History. A two-year appointment as Scientific Leader of the Gulf of St. Lawrence Program at the Bedford Institute of Oceanography intervened in 1972 and 1973 . He collected certain medals, was elected to the Royal Society of Canada in 1954, and appointed Officer of the Order of Canada in 1990. He claims that the best years of his life were those following 1947, when the Fisheries Research vessel "Calanus" was built to his specifications and used in Ungava Bay, Hudson Strait, Frobisher Bay, etc., by him and his associates (all of them McGill people) for many years. She is now abandoned, on her cradle on the beach at Iqaluit, Baffin Island.

Henry Hayward: Henry has family connections in Canada, especially in Vancouver, and I believe the hydro-electric dam on Stave Lake is known as the Hayward Dam. Like Peter Mott, he was an engineering student at Oxford. I met him again in 1938 on my way to Glacier Bay in southern Alaska (or on my way home in the fall; I cannot remember), and he was great fun and full of enthusiasm for more field work. He died in Poona, India, during the war, of an infection which neither Mott nor I have any details of.

Peter Grey Mott: Born in June 1913, Peter Mott has had a distinguished career in surveying, exploration and mountaineering in the Arctic, the Antarctic, and the Himalayas. Following the 1935 expedition described in the present diary, he led two more parties to the same general region of West GreenlandSøndrestrømfjord and the Rasmussen Ice-arm -in 1936 and 1938, and it was he who arranged for the memorial to Michael Atter in the official naming of Mount Atter. In 1939 he joined Shipton's expedition to the Karakorum Himalaya in charge of mapping. During the war he joined the Royal Engineers attached to the Indian Military Survey. From then on he became a professional surveyor; in 1952 he became Technical Director of Hunting Aerosurveys Ltd. In 1955-57 he was Organiser and Leader of the Falkland Islands and Dependencies Aerial Survey Expedition, engaged on behalf of the Colonial Office on air photography and ground control of the British sector of the Antarctic. He was awarded the President's Medal of the Photogrammetric Society, and became President of that Society in 1966 . In 1978 he retired from the Hunting Group after 32 years of service with it, and from the Survey Group of which he had become Managing Director in 1972. He has a number of technical papers to his name, published in various scientific journals.

1. Sarfartok River, "the place of much current" is now called Kugsuak, "the big river".

2. An official account of this expedition was given by Henry Hayward in the Royal Geographical Society in London and published under the title "The Oxford University Greenland Expedition, 1935: A Paper read at the Afternoon Meeting of the Society on 6 April 1936," The Geographical Journal 88 (1936), 148-162.

3. This was Manne Rasmussen, son of the great Knud Rasmussen, Danish-Greenland explorer, whose trading company based at Thule, in Northwest Greenland, owned the schooner "Dannebrog."

4. Charles Stuart Calverley's (1831-1884) poem Dover to Munich reads:

We've a nun here (called Therèse)

Two couriers out of place,

One Yankee with a face Like a ferret's;

And three youths in scarlet caps Drinking chocolate and schnappsA diet which perhaps Has its merits.

Complete Works (London, 1920), 32-33. 
5. George Robey, contemporary British comedian, (1869-1954).

6. Dogleap was the name of the farm in Northern Ireland owned by my aunt Dorothy Robertson, close to the town of Limavady (page 3). The "big doings in Derry" refer to the celebration of the Battle of the Boyne (the 12 th of July).

7. Cotswolds, a region of central southern England, west of Oxford.

8. See note 6 above.

9. The Evidence of Our Senses by A.W.P. Wolters (1838- ), London, 1933.

10. Ballymaglin, a small farm owned by my uncle Jack Moody and his wife Anna Robertson. Both the Dogleap and Ballymaglin were (and are) on the river Roe in County Derry.

11. See note 10 above.

12. Harry's Hole, a deep pool surrounded by rocky shore, County Donegal. Sometimes there were seals in it.

13. Charles Sorley (1895-1915), English poet.

14. Jean Taylor, later Lady Medawar, wife of Sir Peter Brian Medawar, Nobel Prize winner in Biology and Medicine (1915-1987).

15. Peter Venters, boyhood friend in Edinburgh and fellow student. Teacher of French language.

16. See note 14 above.

17. Moira, my younger sister, later Chairperson of the Committee on Ice in Navigable Waters, Defense Research Board, Ottawa, and Officer of the Order of Canada. Ronald was Ronald Bruce Turnbull (1914- ).

18. "Dry brewing," for some reason, was the name given to the preparation of a sweet cocoa made by boys at Fettes College, Edinburgh. On certain occasions it was considered illegal, I forget why.

19. The doctor's name is probably misspelt; I knew no Danish at the time. More probably "Federspiel"?

20. Dr. Reuter, Austrian medical doctor and friend of the family.
21. Richard Tauber (1892-1948), Austrian born tenor, later a British subject.

22. Dr. Hobbs, of Chicago, had made a camp at the head of Søndre Strømfjord a few years before this episode. Camp Evans was later chosen as the site of the airport known as "Bluie West Eight" during the war; now a commercial airport. Hobbs had asked us to retrieve his radiotron(s).

23. Collapsible canoe made in Austria.

24. Hoosh, stew or the like, of infinite variety.

25. Scree (talus): steep slope of broken rock.

26. "The Island" was the name we gave to a conspicuous hill up the valley of the Sarfartok River. The Lake referred to in the entry for Thursday, 15 th was close to the ice-cap.

27. Paraffin, British for Kerosene.

28. See note 26 above.

29. Peter Mott went on to great things in surveying and polar work, including two years in the Antarctic. See also biography above.

30. Bep, my cousin Elizabeth Robertson, living in Edinburgh.

31. Friends in Ulster.

32. Dunfanaghy in Donegal country, N.W. Ireland.

33. Henry Havergal, music master at Fetres College, Edinburgh, in my day; later distinguished conductor, Glasgow Philharmonic, etc.

34. Thomas George Longstaff (1875-1964), British geographer and unofficial advisor to the Oxford University Exploration Club.

35. Cherwell, one of the rivers at Oxford, famed in song and story.

36. See note 25 above.

37. The Riddle of the Sands: A Record of Secret Service by Erskine Childers (1913).

38. Similar to "Big Brother" clubs in North America. 
Greenland Adventure: 1935

39. Dr. Max Nicholson was "home agent" for our litrle expedition.

40. "Grønlands Styrelse," the Danish government administration of Greenland. 